\title{
Tingkah Laku Estrus Rusa Timor (Cervus timorensis) Betina yang di Suplementasi dengan Magnesium, Seng dan Selenium pada Satu Siklus Estrus
}

\author{
Estrus behavior of Timor Deer (Cervus timorensis) Females in the Supplementation with \\ Magnesium, Zinc and Selenium on the Estrus Cycle
}

\author{
A. Setiyono, D. Samsudewa danY. S. Ondho \\ Program Studi Peternakan Fakultas Peternakan dan Pertanian \\ Universitas Diponegoro Semarang \\ Jl. drh. R. Soejono Koesoemowardojo, Tembalang, Kota Semarang 50275 \\ setiyonoachmad@gmail.com
}

\begin{abstract}
The aims of this research was observed the performance of the behaviour of the Timor deer females during estrus cycle andobserved the influence of mineral supplementation of zinc, selenium and magnesium to the female Timor deer behavior during estrus cycle. Research material is the Timor deer (Rusa timorensis) females as much as 10 tails, poel 2 and BCS 2-3,25 with criteria of physical appearance are healthy and have ever been partus. The applied treatment is $\mathrm{T} 0$ (control) without the mineral supplementation, and T1 with mineral supplementation.The parameters of behaviour was observed (urinasi, following, kissing other female, walking around the fence, shouting, eat and drink). The results showed that the mineral supplementation has no significant different $(\mathrm{P}>0.05)$ to the shouting behaviour, whereas behavior in urinasi, following, kissing other female, walking around the fence, eat and drink shows the sinificant difference $(\mathrm{P}<0.05)$. The conclusion of the research are the reproductive behavior of female timor deer including urinasi, following, kissing other female, walking around the fence, shouting, eat and drink. Supplementation of mineral affected to the reproductive behavior of female deer.
\end{abstract}

Key words: mineral, magnesium, zinc, selenium, Timor deer, behaviour, estrus

\begin{abstract}
ABSTRAK
Tujuan dilaksanakannya penelitian ini untuk mengetahui tingkah laku rusa Timor betina selama satu siklus estrus dan mengetahui pengaruh suplementasi mineral seng $(\mathrm{Zn})$, Selenium $(\mathrm{Se})$ dan Magnesium $(\mathrm{Mg})$ terhadap tingkah laku rusa Timor betina selama siklus estrus. Materi yang digunakan adalah rusa Timor (Rusa timorensis) betina sebanyak 10 ekor, poel 2 dan BCS 2,5-3,25 dengan kriteria penampilan fisik sehat dan sudah pernah partus. Perlakuan yang diterapkan adalah T0 (kontrol) tanpa suplementasi mineral, dan T1 dengan suplementasi mineral. Parameter tingkah laku yang diamati adalah urinasi, following, kissing other female, walking around the fence, shouting, standing heat, makan dan minum. Data tingkah laku urinasi, following, kissing other female, walking around the fence, shouting, standing heat, makan dan minum dianalisis dengan uji Mann Whitney U-test. Hasil penelitian menunjukkan bahwa suplementasi mineral tidak berpengaruh signifikan $(\mathrm{P}>0,05)$ terhadap shouting, sedangkan pada urinasi, following, kissing other female, walking around the fence, makan dan minum menunjukan perbedaan yang nyata $(\mathrm{P}<0,05)$. Simpulan dari penelitian ini adalah selama satu siklus estrus rusa Timor menunjukkan tingkah laku urinasi, following, kissing other female, walking around the fence, shouting, makan dan minum serta suplementasi magnesium, seng dan selenium dapat mempengaruhi tingkah laku estrus rusa Timor betina.
\end{abstract}

Kata Kunci: mineral, magnesium, zinc, selenium, Rusa Timor, behaviour, estrus

\section{PENDAHULUAN}

Rusa Timor adalah salah satu satwa harapan yang berpotensi untuk menghasikan daging, kulit dan velvet (ranggah muda). Potensi karkas daging rusa relatif lebih tinggi ditunjukkan dengan presentasi karkas yang mencapai $60-70 \%$ dari bobot badan. Tingginya karkas rusa belum didukung dengan manajemen reproduksi yang baik dikalangan 
penangkaran, karena penangkar masih menerapkan metode kawin alami, sedangkan kawin alami berpotensi besar menyebabkan terjadi penurunan peforman dan terjadinya cacat genetic karena inbreeding. Upaya untuk menghindari inbreeding dapat dilakukan dengan menerapkan IB (Inseminasi Buatan) yang merupakan salah satu teknologi bio reproduksi. IB akan sangat efektif apabila didukung dengan data tingkah laku rusa betina untuk menentukan waktu puncak estrus.

Tingkah laku estrus dapat dilihat melalui gejala meningkatnya frekuensi urinasi, following, kissing other female, walking around the fence, shouting, makan dan minum. Tingkah laku akan saling berhubungan satu dengan yang lainnya pada satu siklus estrus. Tingkah laku rusa Timor betina akan semakin nampak apabila didukung dengan suplementasi mineral. Suplementasi unsur mineral yang sangat diperlukan untuk menunjang reproduksi yaitu magnesium $(\mathrm{Mg})$, selenium $(\mathrm{Se})$ dan Seng (Zn). Suplementasi unsur mineral Mg, Zn dan Se akan efektif dalam kadar tertentu dalam pakan rusa, tetapi suplementasi mineral masih sulit ditentukan, karena setiap individu rusa memiliki perbedaan dalam kebutuhan mineral. Kebutuhan mineral rusa dapat dipenuhi dengan mineral blok, karena mineral blok diasumsikan menyerupai batu-batuan dihabitat alami sehingga apabila rusa Timor betina kekurangan mineral dapat mengkonsumsi mineral blok. Harapanya dengan suplementasi Mg, Zn dan Se yang terdapat pada mineral blok, kebutuhan mineral didalam tubuh rusa akan terpenuhi sehingga dapat menampakkan tingkah laku pada saat estrus.

Tujuan dari penelitian ini adalah untuk mengetahui tingkah laku rusa Timor betina selama satu siklus estrus dan mengetahui pengaruh suplementasi magnesium, seng dan selenium terhadap tingkah laku rusa Timor betina selama satu siklus estrus. Manfaat dari penelitian ini adalah memberikan informasi kepada penangkar bahwa suplementasi magnesium, seng dan selenium dapat meningkatkan kualitas birahi yang akan menampakkan tingkah laku pada puncak estrus lebih nampak dan memberikan informasi macammacam tingkah laku yang muncul pada saat estrus.

\section{MATERI DAN METODE}

Penelitian ini dilaksanakan pada tanggal 10 Maret sampai 30 Mei 2016 di Desa Margorejo, Kecamatan Dawe, Kabupaten Kudus, Jawa Tengah.

Materi yang digunakan untuk pengamatan tingkah laku rusa Timor pada satu siklus estrus berupa Rusa Timor (Rusa timorensis) betina yang telah disinkronisasi estrus dengan BCS $2-3,25$ dan poel 2 sebanyak 10 ekor. Kondisi rusa sudah pernah melahirkan dan sehat fisik.

Pengamatan tingkah laku estrus dilaksanakan setelah implan spon MPA dicabut. Pengamatan tingkah laku rusa Timor dilakukan selama 21 hari dengan menyesuaikan siklus estrus rusa Timor betina. Pengamatan dilakukan ditempat pengamatan dengan jarak $15 \mathrm{~m}$ dari 
kandang penelitian yang diharapkan kehadiran peneliti dan petugas kandang tidak mengganggu aktifitas tingkah laku dan menyebabkan stress pada rusa Timor betina. Pengamatan tingkah laku estrus selama 21 hari menggunakan recording manual (buku pengamatan tingkah laku) berupa tabel ethogram.

Perlakuan pemberian mineral ke rusa Timor betina yang berisikan magnesium, seng dan selenium didalam mineral blok selama 8 minggu secara adlibitum. Perlakuan yang digunakanan pada penelitian ini menggunakan 10 ekor rusa Timor betina dengan 2 perlakuan yaitu kandang T0 berisikan 5 ekor rusa Timor betina yang tidak diberikan suplementasi mineral blok (kontrol) dan T1 berisikan 5 ekor rusa diberikan mineral didalam kandang T1 secara menggantung.

Sinkronisasi estrus rusa Timor betina dilakukan terhadap 10 ekor rusa betina dengan menggunakan spon yang diimplan MPA secara aseptis kedalam vagina selama 16 hari.

Parameter tingkah laku rusa Timor betina yang diambil selama satu siklus estrus meliputi yaitu frekuensi tingkah laku urinasi, following, kissing other female dan walking around the fence. Data tingkah laku selama satu siklus estrus ditampilkan dalam bentuk tabel, dianalisis statistik dengan menggunakan Mann Whitney Utest.

\section{HASIL DAN PEMBAHASAN}

\section{Urinasi}

Tingkah laku urinasi rusa Timor betina dapat dijadikan sebagai penanda puncak estrus, karena pada estrus akan terjadi peningkatan jumlah frekuensi urinasi dibandingkan dengan urinasi tidak saat estrus. Tingkah laku urinasi dimulai dengan rusa betina melebarkan kedua kaki belakang, mengangkat ekor serta mengeluarkan urin. Setiawan et al. (2015) menyatakan bahwa urinasi saat estrus rusa Timor betina menunjukkan peningakatan jumlah frekuensi urinasi lebih banyak dan urin yang keluar sedikit.

Rataan frekuensi urinasi yang disajikan dalam Tabel 1, menunjukkan frekuensi urinasi pada fase proestrus lebih tinggi dibandingkan dengan fase lainnya yang disebabkan oleh rangsangan dari rusa jantan dan mulainya peningkatan hormon estrogen. Rangsangan rusa jantan ke betina salah satunya dengan melakukan jilatan ketubuh dan organ kelamin. Rusa jantan melakukan jilatan ke betina karena tertarik bau pheromone yang dikeluarkan oleh lendir dan urin rusa betina. Rangsangan berupa jilatan ke organ kelamin dari rusa jantan dapat meningkatkan produksi estrogen rusa betina dan berpengaruh tehadap frekuensi urinasi saat siklus estrus. Pragiwit (2007) mengungkapkan bahwa rangsangan dapat berasal rangsangan dari dalam tubuh dapat berupa hormon sedangkan rangsangan dari luar dapat berupa rangsangan penciuman, pendengaran dan penglihatan yang dapat mempengaruhi tingkah laku estrus. 
Tabel 1. Rataan Frekuensi Tingkah Laku Urinasi

\begin{tabular}{|c|c|c|c|c|}
\hline \multirow{3}{*}{ Fase } & \multicolumn{4}{|c|}{ Perlakuan } \\
\hline & \multicolumn{2}{|c|}{ T0 } & \multicolumn{2}{|c|}{ T1 } \\
\hline & Range & Rataan & Range & Rataan \\
\hline & ------- & --- (Ka & (hari) -- & --------- \\
\hline Proestrus & $0-3$ & 1,70 & $2-30$ & 10,40 \\
\hline Estrus & $0-6$ & 1,20 & $0-15$ & 4,53 \\
\hline Metestrus & $0-3$ & 1,10 & $0-4$ & 2,20 \\
\hline Diestrus & $0-5$ & 2,07 & $0-19$ & 3,53 \\
\hline
\end{tabular}

Hasil rataan frekuensi urinasi pada Tabel 1, yang diuji dengan metode Mann Whitney U-Test menunjukkan bahwa pada T0 dan $\mathrm{T} 1$ berbeda nyata $(\mathrm{P}<0.05)$. Perbedaan frekuensi urinasi pada perlakuan T0 dan T1 disebabkan oleh suplementasi mineral magnesium $(\mathrm{Mg})$, seng ( $\mathrm{Zn})$ dan selenium (Se) dalam mineral blok yang berpengaruh terhadap dinamika estrogen rusa betina. Kekurangan asupan $\mathrm{Mg}$ didalam tubuh dapat mempengaruhi produksi estrogen karena $\mathrm{Mg}$ dibutuhkan untuk transport kalsium, natrium dan kalium. Kalsium, natrium dan kalium dilibatkan dalam sintesis protein untuk pembentukan second messenger dalam bentuk Cyclic Adenosinemonophosphate (cAMP). Malingkas et al. (2015) berpendapat bahwa $\mathrm{Mg}$ dibutuhkan untuk transpor ion-ion lainnya seperti kalium dan kalsium dan dilibatkan dalam sintesis protein, khususnya pada pembentukan cAMP.

\section{Cyclic Adenosinemonophosphate} (cAMP) didalam tubuh berfungsi untuk merangsang reaksi enzim adenilat kinase untuk membawa pesan dari hormon FSH (Follicle-stimulating hormone) ke dalam sel theca interna di ovarium untuk menghasilkan estrogen. Lili (2011) berpendapat bahwa $\mathrm{Mg}$ dibutuhkan dalam sintesis cAMP untuk reaksi enzim adenilat siklase yang memainkan peran penting dalam proses komunikasi antara gonadotrophin (LH, FSH) dan ovarium. Suplementasi seng (Zn) dalam mineral blok berpengaruh nyata terhadap estrogen rusa betina karena seng ( $\mathrm{Zn}$ ) berperan aktif dalam pertumbuhan dan pembelahan sel diovarium. Hidayat (1999) menyatakan bahwa $\mathrm{Zn}$ mempunyai fungsi fisiologi untuk pertumbuhan dan pembelahan sel, antioksidan, perkembangan organ kelamin, kekebalan sel, hormonal, adaptasi gelap, pengecapan serta nafsu makan.

Pertumbuhan dan pembelahan sel ovarium dimulai dari fase proestrus. Hal tersebut sesuai dengan pendapat Frandson (1996) bahwa fase proestrus atau fase mulainya peningkatan hormon estrogen yang meningkatkan perkembangan folikel. Pertumbuhan folikel didalam ovarium dimulai dari folikel primer, sekunder, tersier dan yang terakhir akan menjadi folikel de graff. Tanpa adanya $\mathrm{Zn}$ didalam tubuh proses perkembangan folikel didalam tubuh menjadi terganggu dan berpengaruh terhadap mekanisme estrogen, karena estrogen diproduksi didalam sel theca interterna. Hamny (2010) menyatakan bahwa proses perkembangan folikel didalam ovarium dapat memengaruhi mekanisme estrogen didalam tubuh.

Selenium (Se) dapat berpengaruh terhadap produksi estrogen, karena selenium bersama vitamin $\mathrm{E}$ berperan merangsang sel granulosa didalam ovarium 
untuk mengeluarkan efektitas enzimatis untuk katalisator aromatisasi androgen menjadi estrogen. Prasdini et al. (2015) menyatakan bahwa Se bersama dengan vitamin $\mathrm{E}$ berperan dalam penghambatan produksi nitric oxide ketika proses produksi estrogen di sel granulosa dan proliferasi (fase pertumbuhan sel dan jaringan) dari sel granulosa ovarium untuk mensintesis estradiol $17 \beta$ dengan cara menstimulasi kelenjar hipotalamus untuk meng-hasilkan FSH dan LH.

Peningkatan dinamika estrogen akibat suplementasi magnesium, seng dan selenium dapat mempengaruhi hormone adenocorticotropin (ACTH) dihipofisa meningkat dan ACTH akan menuju adrenal untuk merangsang pembentukan aldosteron. Produksi aldosteron oleh kelenjar adrenal akan direspon oleh sel JG (juxtaglomerular) di ginjal dengan mengubah hormon aldosteron menjadi angiostenin II melalui biosentitesis angiostenin. Biosintesis angiostenin di sel JG dapat berdampak terhadap penyempitan didinding arteri dan menyebabkan peningkatan tekanan darah.

Tekanan darah yang meningkat dapat mengakibatkan atrium jantung menyempit dan volume darah dijantung berkurang. Hadley (2000) berpendapat bahwa prosen biosintesis angiostenin menyebabkan penyempitan dinding arteri dan tekanan darah meningkat. Berkurangnya volume darah dijantung dan peningkatan tekanan darah dapat meningkatkan kinerja dari ginjal, sehingga terjadi diuresis atau produksi urin secara berlebih. Produksi urin yang berlebih dan menyebabkan frekuensi pengeluaran urin pada saat awal estrus akan meningkat sampai puncak estrus. Peningkatan jumlah frekuensi urinasi pada awal estrus bertujuan untuk menarik rusa jantan untuk memberikan cumbuan karena didalam urin rusa betina mengandung pheromone. Trindeli et al. (2009) menyatakan bahwa pheromone yang terdapat pada urin dapat menyebabkan daya tarik ke betina lain, meningkatkan agresifitas pejantan, mempercepat pubertas dan dapat dijadikan sebagai metode sinkronisasi.

\section{Following}

Frekuensi tingkah laku following pada rusa betina menunjukkan fluktuasi selama satu siklus estrus. Rataan frekuensi following pada Tabel 2, menunjukkan puncak frekuensi following TO terdapat pada fase estrus yaitu pada hari ke-3 dengan frekuensi following sebanyak 2,00 kali/hari. Berbeda dengan frekuensi following $\mathrm{T} 1$ yang mengalami puncak pada fase proestrus yaitu pada hari ke-1 dengan nilai frekuensi sebanyak 23,80 kali/hari. Perbedaan rataan frekuensi following disebabkan puncak frekuensi urinasi, walking around the fence dan shouting pada $\mathrm{T} 1$ berada pada fase proestrus berbeda dengan T0 yang mengalami puncak urinasi, walking around the fence dan shouting pada fase estrus. Hal tersebut menyebabkan rataan frekuensi following T1 lebih awal dari pada T0. 
Tabel 2. Rataan Frekuensi Tingkah Laku Following

\begin{tabular}{|c|c|c|c|c|}
\hline \multirow{3}{*}{ Fase } & \multicolumn{4}{|c|}{ Perlakuan } \\
\hline & \multicolumn{2}{|c|}{ T0 } & \multicolumn{2}{|c|}{ T1 } \\
\hline & Range & Rataan & Range & Rataan \\
\hline & ------- & ---- $(\mathrm{Ka}$ & hari) -- & --------- \\
\hline Proestrus & $0-3$ & 1,00 & $2-30$ & 14,50 \\
\hline Estrus & $0-5$ & 1,47 & $0-15$ & 6,13 \\
\hline Metestrus & $0-1$ & 0,20 & $0-4$ & 1,5 \\
\hline Diestrus & $0-5$ & 0,09 & $0-19$ & 0,56 \\
\hline
\end{tabular}

Hasil rataan frekuensi following yang tersaji pada Tabel 2, yang telah diuji statistik menggunakan metode Mann Whitney U-Test menunjukkan bahwa T0 dan $\mathrm{T} 1$ berbeda nyata $(\mathrm{P}<0.05)$. Perbedaan nyata T0 dan T1 disebabkan oleh suplementasi mineral magnesium, seng dan selenium dalam mineral blok yang mempengaruhi dinamika estrogen rusa Timor Betina.

Peningkatan estrogen karena suplementasi magnesium, seng dan selenium dapat merangsang produksi lendir dan urinasi. Semakin tingginya frekuensi urinasi dan pengeluaran lendir oleh rusa betina lain maka akan semakin tinggi frekuensi following yang ditunjukan oleh rusa betina. Pheromone yang terdapat dilendir dan urin menyebabkan ketertarikan dan dapat merangsang rusa Timor betina melakukan following ke betina lain. Hadley (2000) menyatakan bahwa pheromone diklasifikasikan menjadi dua tipe, yaitu tipe pelepas pheromone, yang menyebabkan reaksi tingkah laku reproduksi dan primer pheromone, yang menyebabkan efek lambat, seperti perubahan sistem endokrin dan reproduksi.
Pheromone urin pada rusa Timor betina dalam bentuk alifatik (dodecylpropionat-aphodisin) dan bersifat aromatik, sedangkan pheromone lendir dalam bentuk dodecyl-propionat-aphodisin. Trindeli et al. (2009) menyatakan bahwa pheromone yang dihasilkan dari urin betina yaitu pheromone dalam bentuk 2,5-dimetil pyraine, pheromone ini akan diterima di vameronasal organ (VNO) dibagian hidung dan pheromone dalam kelenjar vagina dan kelenjar preputial betina dalam bentuk dodecyl-propionat-aphodisin.

Pheromone yang urin dan lendir serviks yang keluar disekitar vulva akan menyebar disekitar kandang melalui udara. Hadley (2000) menyatakan bahwa pheromone pada umumnya dalam bentuk alifatik (senyawa aromatisasi) sehingga mudah untuk menguap dan penyebarannya lewat udara. Penyebaran pheromone disekitar kandang akan diterima oleh rusa Timor betina melalui organ vamenorasal yang berada dihidung. Sinyal pheromone diteruskan ke hipotalamus dan LH-RH akan meningkat karena pengaruh merespon pheromone. Ketika hormon tersebut berada di hipotalamus dan melakukan feedback possitif dengan $\mathrm{CRH}$ yang mengakibatkan peningkatan sekresi hormon adrenalin oleh kelenjar adrenal. Peningkatan hormon adrenalin menyebabkan kegelisan, sehingga rusa betina akan mengekspresikan tingkah laku following dengan melakukan pencarian terhadap bau pheromone yang dihasilkan oleh urin dan lendir betina lain. 


\section{Kissing Other Female}

Tingkah laku kissing other female dimulai ketika rusa betina mencium dan menjilati betina lain pada daerah vulva, ekor dan bagian tubuh lain dengan cara menggerakkan muka dari bawah keatas maupun sebaliknya. Kissing other female merupakan tingkah laku yang dapat menandakan rusa Timor betina melakukan homoseksual. Setiawan et al. (2015) menyatakan bahwa kissing other female muncul karena betina tidak mendapat respon dari pejatan pada saat estrus.

Tabel 3. Rataan Frekuensi TingkahLaku Kissing Other Female

\begin{tabular}{lcccc}
\hline \multirow{2}{*}{ Fase } & \multicolumn{4}{c}{ Perlakuan } \\
\cline { 2 - 5 } & \multicolumn{2}{c}{ T0 } & \multicolumn{2}{c}{ T1 } \\
\cline { 2 - 5 } & Range & Rataan & Range & Rataan \\
\hline \multirow{3}{*}{ Proestrus } & $0-13$ & 2,80 & $1-20$ & 9,60 \\
Estrus & $0-6$ & 2,00 & $0-13$ & 3,80 \\
Metestrus & $0-3$ & 1,00 & $0-8$ & 2,70 \\
Diestrus & $0-3$ & 0,29 & $0-14$ & 1,30 \\
\hline
\end{tabular}

Hasil rataan frekuensi kissing other female yang tersaji pada Tabel 3, yang telah diuji statistik menggunakan metode uji Mann Whitney U-Test menunjukkan T0 dan $\mathrm{T} 1$ berbeda nyata $(\mathrm{P}<0.05)$. Perbedaan yang nyata disebabkan oleh suplementasi mineral magnesium, seng dan selenium dalam mineral blok yang dapat mempengaruhi estrogen didalam tubuh rusa Timor Betina. Meningkatnya estrogen menyebabkan peningkatan sekresi urin dan lendir pada awal estrus. Peningkatan sekresi urinasi dan lendir pada awal estrus menyebabkan pengeluaran pheromone disekitar kandang akan meningkat.
Bau pheromone di urin dan lendir tersebar disekitar kandang pengamatan karena pheromone bersifat aromatik. Bau pheromone akan diterima betina lain dibagian organ vameronasal dibagian hidung yang kemudian menstimulasi hipotalmus dan menyebabkan betina melakukan kissing other female karena ketertarikan rusa Timor betina untuk melakukan cumbuan terhadap betina lain. Hal ini sesuai pendapat Tirindeli et al. (2009) yang menyatakan bahwa Pheromone yang dikeluarkan dalam kelenjar vagina dan kelenjar preputial betina dalam bentuk dodecyl-propionat-aphodisindan dapat menyebabkan tingkah laku menjilati organ kelamin pada betina dan jantan serta mempengaruhi tingkah laku mengawini pada jantan. Aktivitas cumbuan sesama jenis disebabkan oleh rusa Timor Betina tidak mendapatkan cumbuan dari rusa jantan.

\section{Walking around the fence}

Walking around the fence atau tingkah laku betina mengililingi kandang dicirikan dengan rusa Timor betina mulai menjauhi kawanan dengan menepi dipagar kandang, menengok pejantan dikandang lain dan dilanjutkan dengan memutari kandang beberapa kali disertai dengan shouting untuk menarik lawan jenis. Tingkah laku walking around the fence merupakan eskpresi kegelisahan dari betina untuk menarik perhatian pejantan. Hal tersebut sesuai dengan pendapat Setiawan et al. (2015) yang menyatakan bahwa tingkah laku kegelisahan dicirikan dengan rusa betina yang sering menyendiri 
menjauh kawanan, berjala mengelilingi kandang berulang kali untuk mencari perhatian pejantan

Tabel 4. Rataan Frekuensi Tingkah Laku Walking Around the Fence

\begin{tabular}{|c|c|c|c|c|}
\hline \multirow{3}{*}{ Fase } & \multicolumn{4}{|c|}{ Perlakuan } \\
\hline & \multicolumn{2}{|c|}{ T0 } & \multicolumn{2}{|c|}{ T1 } \\
\hline & Range & Rataan & Range & Rataan \\
\hline & --------- & --- $(\mathrm{Ka}$ & (hari) -- & --------- \\
\hline Proestrus & $0-1$ & 0,10 & $1-25$ & 8,80 \\
\hline Estrus & $0-27$ & 2,87 & $0-18$ & 3,93 \\
\hline Metestrus & $0-4$ & 0,50 & $0-1$ & 0,70 \\
\hline Diestrus & $0-4$ & 0,21 & $0-15$ & 1,24 \\
\hline
\end{tabular}

Rataan frekuensi walking around the fence yang tersaji pada Tabel 4, yang telah diuji statistik menggunakan metode Uji Mann Whitney U-Test menunjukkan bahwa T0 dan $\mathrm{T} 1$ berbeda nyata $(\mathrm{P}<0.05)$. Perbedaan yang nyata disebabkan oleh suplementasi mineral magnesium, seng dan selenium dalam mineral blok yang dapat mempengaruhi estrogen didalam tubuh rusa Timor Betina.

Peningkatan estrogen pada T0 dan T1 pada awal sampai puncak estrus akan mengakibatkan peningkatan frekuensi walking around the fence. Peningkatan estrogen pada awal proestrus sampai estrus dapat memicu produksi aldosteron di kelenjar adrenal. Aldosteron dapat mengakibatkan tingkat kegelisahan dengan terjadi peningkatan tekanan darah, frekuensi denyut jantung dan nafas. Peningkatan estrogen didalam tubuh mengakibatkan rusa Timor betina memiliki keinginan untuk dikawini oleh pejantan. Keinginan dicumbu oleh rusa jantan, rusa betina akan melakukan walking around the fence beberapa kali sampai rusa jantan tertarik untuk mendekati. Keinginan rusa Timor betina untuk dikawini akan diekspresikan dengan mengelilingi kandang beberapa kali dengan sebelumnya memojok ke pagar untuk melihat rusa jantan diluar kandang, frekuensi urinasi meningkat dan diiringi dengan shouting.

\section{Shouting}

Shouting atau mengeluarkan suara melengking merupakan tingkah laku rusa betina untuk berkomunikasi dengan rusa lainnya. rusa Timor betina melakukan shouting diiringi dengan tingkah laku walking around the fence. Shouting muncul untuk menarik perhatian pejantan dan eskpresi dari kegelisahan dari betina karena tidak mendapatkan cumbuan dari pejantan. Samsudewa (2011) menyatakan bahwa tingkah laku estrus ditunjukan dengan shouting 2-6 kali dan diikuti dengan gelisah.

Hasil rataan frekuensi shouting yang tersaji pada Tabel 5, yang telah diuji statistik menggunakan metode Uji Mann Whitney U-Test menunjukkan bahwa T0 dan $\mathrm{T} 1$ tidak berbeda nyata $(\mathrm{P}<0.05)$. Tidak perbedaan yang nyata disebabkan oleh suplementasi mineral $\mathrm{Mg}, \mathrm{Zn}$ dan Se dalam mineral blok yang dapat meningkatkan dinamika estrogen tidak berpengaruh terhadap frekuensi shouting. Meningkatkannya estrogen pada awal proestrus mengakibatkan meningkatnya dalam aldosterone dalam kelenjar adrenal. Aldosteron meningkat dapat mengakibatkan kegelisahan pada rusa Timor betina. Kegelisahan pada rusa Timor diekspresikan 
dengan melakukan shouting untuk menarik rusa jantan.

Tabel 5. Rataan Frekuensi Tingkah Laku Shouting

\begin{tabular}{|c|c|c|c|c|}
\hline \multirow{3}{*}{ Fase } & \multicolumn{4}{|c|}{ Perlakuan } \\
\hline & \multicolumn{2}{|c|}{ T0 } & \multicolumn{2}{|c|}{ T1 } \\
\hline & Range & Rataan & Range & Rataan \\
\hline & ------- & $---(\mathrm{Ka}$ & hari) & ------ \\
\hline Proestrus & $0-2$ & 0,30 & $0-7$ & 0,90 \\
\hline Estrus & $0-48$ & 3,33 & 1 & 0,07 \\
\hline Metestrus & 0 & 0 & 0 & 0 \\
\hline Diestrus & $0-29$ & 3,01 & $0-17$ & 1,54 \\
\hline
\end{tabular}

\section{Makan}

Tingkah laku rusa Timor pada satu satu Siklus estrus berkaitan dengan jumlah frekuensi makan. Frekuensi makan muncul semakin banyak karena ada rangsangan dan gangguan dari pejantan dan betina lain.

Tabel 6. Rataan Frekuensi Tingkah Laku Makan

\begin{tabular}{|c|c|c|c|c|}
\hline \multirow{3}{*}{ Fase } & \multicolumn{4}{|c|}{ Perlakuan } \\
\hline & \multicolumn{2}{|c|}{ T0 } & \multicolumn{2}{|c|}{ T1 } \\
\hline & Range & Rataan & Range & Rataan \\
\hline & --------- & --- (Kali & lari) ---- & -------- \\
\hline Proestrus & $46-81$ & 60,30 & $45-81$ & 58,75 \\
\hline Estrus & $14-47$ & 27,60 & $10-59$ & 28,27 \\
\hline Metestrus & $12-22$ & 15,50 & $14-40$ & 27,20 \\
\hline Diestrus & $4-37$ & 17,81 & $5-52$ & 21,69 \\
\hline
\end{tabular}

Frekuensi makan yang tersaji dalam Tabel 6, menunjukkan rataan frekuensi makan tertinggi terletak pada proestrus yaitu pada hari 1. Tingginya frekuensi makan pada awal siklus estrus, karena pada saat proestrus mulai terjadi peningkatan estrogen didalam tubuh dan rangsangan cumbuan dari pejantan serta betina lain.
Peningkatan estrogen pada proestrus dan estrus menyebabkan rasa lapar pada rusa Timor betina sehingga meningkatnya konsumsi pakan. Ransangan cumbuan dari betina dan pejantan lain menyebabkan kegelisahan pada rusa Timor betina dan menimbulkan frekuensi makan meningkat.

Hasil rataan frekuensi makan yang tersaji pada Tabel 6, yang telah diuji statistik menggunakan metode Uji Mann Whitney U-Test menunjukkan bahwa T0 dan $\mathrm{T} 1$ berbeda nyata $(\mathrm{P}>0.05)$. Perbedaan yang nyata disebabkan oleh suplementasi mineral magnesium, seng dan selenium dalam mineral blok yang dapat meningkatkan estrogen didalam tubuh rusa betina. Meningkatnya estrogen didalam tubuh rusa Timor mengakibatkan naiknya hormon aldosteron dan LH-RH didalam hipotalamus. LH-RH berfungsi untuk meningkatkan nafsu makan. Hal ini sesuai dengan pendapat Hadley (2000) yang menyatakan bahwa LH dan VMH dapat berfungsi sebagai glucoreceptor dengan memantau kadar glukosa dalam darah untuk mengontrol asupan makanan didalam tubuh. Meningkatnya nafsu makan rusa Timor betina diiringi dengan kegelisan yang disebabkan oleh aldosteron. Kegelisahan yang timbul pada rusa Timor betina mengakibatkan meingkatkan aktivitas urinasi, minum, following, WAF, KOF dan shouting. Peningkatan aktifitas pada rusa Timor betina dan aktifitas cumbuan oleh pejantan mengakibatkan frekuensi makan meningkat. 


\section{Minum}

Tingkah laku minum dicirikan ketika ternak mendekat ke bak penampung air, menyentuh air dengan mulut dan memasukan air kedalam mulut. Tingkah laku minum dapat dijadikan sebagai indikator puncak estrus karena pada saat estrus frekuensi urinasi dan minum akan meningkat.

Rataan frekuensi minum pada tabel 7, menunjukkan bahwa titik puncak frekuensi makan terletak pada proestrus karena saat fase proestrus merupakan fase mulainya peningkatan dinamika estrogen didalam tubuh dan rangsangan cumbuan dari rusa Timor jantan serta betina lain. Meningkatnya aktifitas tingkah laku cumbuan pada saat proestrus yang berasal dari rusa Timor jantan dan betina lain menyebabkan jumlah frekuensi minum lebih tinggi dari pada fase estrus lainnya.

Tabel 7. Rataan Frekuensi Tingkah Laku Minum

\begin{tabular}{|c|c|c|c|c|}
\hline \multirow{3}{*}{ Fase } & \multicolumn{4}{|c|}{ Perlakuan } \\
\hline & \multicolumn{2}{|c|}{ T0 } & \multicolumn{2}{|c|}{ T1 } \\
\hline & Range & Rataan & Range & Rataan \\
\hline & \multicolumn{4}{|c|}{ 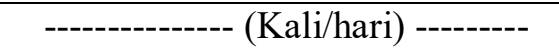 } \\
\hline Proestrus & $1-7$ & 3,60 & $2-10$ & 6,10 \\
\hline Estrus & $0-2$ & 0,87 & $0-12$ & 4,93 \\
\hline Metestrus & $0-1$ & 0,50 & $0-2$ & 0,70 \\
\hline Diestrus & $0-2$ & 0,23 & $0-6$ & 0,79 \\
\hline
\end{tabular}

Hasil rataan frekuensi minum yang tersaji pada Tabel 7, yang telah diuji statistik menggunakan metode Mann Whitney U-Test menunjukkan bahwa T0 dan $\mathrm{T} 1$ berbeda nyata $(\mathrm{P}<0.05)$. Perbedaan yang nyata disebabkan oleh suplementasi mineral magnesium, seng dan selenium yang terdapat dalam mineral blok yang dapat meningkatkan dinamika estrogen didalam tubuh rusa Timor Betina. Peningkatan estrogen ketika awal proestrus mengakibatkan peningkatan sekresi ACTH yang dapat mempengaruhi kelenjar adrenal untuk mensekresikan kortisol. Peningkatan kortisol dalam darah akan direspon oleh organ hati untuk mengasilkan glukosa melalui proses glukonegenesis.

Glukosa dari hati didistribusikan keseluruh tubuh melalui pembuluh darah. Semakin tingginya kadar kortisol didalam darah mengakibatkan tinginya kadar glukosa dan dapat terjadinya hyperglycemia. Hal tersebut sesuai dengan pendapat Hadley (2000) menyatakan bahwa peningkatan kadar kortisol dalam tubuh dapat mengakibatkan hyperglycemia atau kadar gula darah yang tinggi didalam darah. Meningkatnya kadar glukosa dalam darah menyebabkan tekanan osmotik didalam tubuh yang menakibatkan ginjal melakukan pembuangan glukosa melalui urin yang akan menyebabkan diuresis atau pengeluaran urin secara berlebih. Pengeluaran glukosa dalam urin yang berlebihan akan mengakibatkan rusa Timor betina haus yang akan meningkatkan frekuensi minum pada saat estrus. Hal ini sesuai dengan pendapat Arifin (2011) yang menyatakan bahwa Peningkatan kadar glukosa dapat mengakibatkan tekanan osmotic (diuresis osmotic) sehingga glukosa ikut keluar melalui urin dan pengeluaran glukosa yang berlebihan dapat mengakibatkan timbulnya rasa haus dan mulut terasa kering. 


\section{KESIMPULAN}

Berdasarkan pengamatan tingkah laku selama satu siklus estrus menunjukkan bahwa rusa Timor betina menunjukkan tingkah laku urinasi, following, kissing other female dan walking around the fence, shouting, makan dan minum. Suplementasi mineral magnesium $(\mathrm{Mg})$, seng $(\mathrm{Zn})$ dan selenium (Se) berpengaruh nyata terhadap tingkah laku Urinasi, following, kissing other female dan walking around the fence serta tidak berpengaruh terhadap tingkah laku shouting. Suplementasi magnesium, seng dan selenium berperan dalam pembentukan dan meningkatkan dinamika estrogen didalam tubuh rusa Timor Betina. Estrogen didalam tubuh akan mempengaruhi sel-sel target untuk mengaktifkan tingkah laku estrus. Rusa betina akan menunjukkan puncak frekuesi estrus pada fase proestrus.

\section{UCAPAN TERIMAKASIH}

Ucapan terimakasih kepada:

1. Direktorat Penelitian dan Pengabdian kepada masyarakat, Direktorat jenderal Pendidikan Tinggi Kementrian Riset dan Teknologi Republik Indonesia yang telah mendukung kegiatan penelitian ini melalui dana penelitian Fundamental 2016.

2. Alam Surya Wijaya, S.Pt. yang telah membantu dalam pembuatan spon vagina.

3. Kelik Isharyudono, S.T. yang telah mendampingi pembuatan alat pres dan mineral blok.

\section{DAFTAR PUSTAKA}

Arifin, Z. 2008. Beberapa unsur mineral esensial mikro dalam sistem biologi dan metode analisnya. Jurnal Litbang Pertanian. 27 (3) : 99-105

Frandson, R. D. 1996. Anatomi dan Fisiologi Ternak. $4^{\text {th }}$ Ed. Terjemah-an Srigandono dan K. Praseno. Gadjah Mada University Press, Yogyakarta.

Hadley, M. E. 2000. Endocrinology. $8^{\text {th }}$ Ed. Prentice Hall, United State of America.

Hamny, S. Agungpriyono, I. D. Juwita, W. E. Prasetyaningtyas dan I. Nasution. 2010. Karakteristik histologi perkembangan folikel ovarium fase luteal pada Kancil (Trugulus javanicus). Jour. Vet. Sci. and Med. 2 (1) :35-42

Hidayat, A. 1999. Seng (Zinc) : Esensial bagi Kesehatan. Jurnal Kedokteran Trisakti. 18 (1) : 19-29

Lili, H. P. 2011. Gambaran Menstruasi dan Prevalensi Dismenorea pada Mahasiswi Program Studi Pendidikan Dokter UIN Syarif Hidayatullah Jakarta. Skripsi. Universitas Islam Negeri Syarif Hidayatullah, Jakarta.

Malingkas, C. V., M. E. Paruntu dan Y. A. Assa. 2015. Gambaran kadar magnesium serum pada orang lanjut usia dengan umur 60-74 tahun. Jurnal e-Biomedik (eBm), 3 
Pragiwit, W. 2007. Inseminasi Buatan dan Diagnose Kebuntingan Melalui Teknik Ultrasonografi dan Analisa Metabolit Hormon Progesterone pada Rusa Timor (Cervustimorensis) Hasil Sinkronisasi. Tesis. Institut Pertanian Bogor, Bogor

Prasdini, W. A., S. Rahayu dan M. S. Djati. 2015. Level of estrogen and cervical mucus $\mathrm{pH}$ as indicator of estrus after calving toward the provision of selenium-vitamine E on dairy Frisien Holstein (FH). Inter. Jour. of Chem Tech Res. (1) : 190-195
Setiawan, I. A., D. Samsudewa dan Sutiyono. 2015. Pengaruh jumlah pejantan perkandangan terhadap tingkah laku reproduksi rusa Timor (Rusa timorensis) Betina. Jurnal. Agromedia. 33 (2) : 71-76

Samsudewa, D. dan S. S. Capitan. 2011. Reproductive behavior of Timor deer (Rusatimorensis). Jurnal Wartazoa. 21 (3) : 108-113

Tirindelli, R., M. Dibattista, S. Pifferri and A. Menini. 2009. From pheromones to behavior. Jour. Phys. 89 : 921-9 